\title{
FREQUENCY OF FOUR-DIMENSIONAL ORAL HEALTH PROBLEMS ACROSS DENTAL FIELDS - A COMPARATIVE SURVEY OF SLOVENIAN AND INTERNATIONAL DENTISTS
}

\section{POGOSTOST ŠTIRIDIMENZIONALNIH ZOBOZDRAVSTVENIH PROBLEMOV PO SPECIALISTIČNIH PODROČJIH - PRIMERJAVA REZULTATOV ANKETE, OPRAVLJENE MED SLOVENSKIMI IN TUJIMI ZOBOZDRAVNIKI}

Stella SEKULIĆ ${ }^{1,2^{*}}$, Mike T. JOHN² , Katrin BEKES ${ }^{3}$, Mohammad H. AL-HARTHY ${ }^{4}$, Ambra MICHELOTTI5, Daniel R. REISSMANN ${ }^{6}$, Julijana NIKOLOVSKA ${ }^{7}$, Sahityaveera SANIVARAPU ${ }^{8}$, Folake B. LAWAL', Thomas LIST ${ }^{10}$, Asja ČELEBIĆ ${ }^{11}$, Ljiljana STRAJNIĆ ${ }^{12}$, Rodrigo CASASSUS ${ }^{13}$, Kazuyoshi BABA ${ }^{14}$, Martin SCHIMMEL ${ }^{15,16}$, Ama AMUASI ${ }^{17}$, Ruwan D. JAYASINGHE ${ }^{18}$, Sanela STRUJIĆ-POROVIĆ ${ }^{19}$, Christopher C. PECK ${ }^{20}$, Han XIE ${ }^{21}$, Karina HAUGAARD BENDIXEN ${ }^{22}$, Miguel Angel SIMANCASPALLARES $^{23}$, Eka PEREZ-FRANCO ${ }^{24}$, Mohammad Mehdi NAGHIBI SISTAN ${ }^{25}$, Patricia VALERIO ${ }^{26}$, Natalia LETUNOVA $^{27}$, Nazik M NURELHUDA ${ }^{28}$, David W. BARTLETT ${ }^{29}$, Ikeoluwa A. OLUWAFEMI ${ }^{30}$, Saloua DGHOUGHI $^{31}$, Joao N. FERREIRA ${ }^{32}$, Pathamas CHANTARACHERD ${ }^{33}$, Ksenija RENER-SITAR ${ }^{34,35}$

${ }^{1}$ Dental Division, Faculty of Medicine, University of Ljubljana, Ljubljana, Slovenia ${ }^{2}$ Department of Diagnostic and Biological Sciences, School of Dentistry, University of Minnesota, Minneapolis, USA ${ }^{3}$ Department of Pediatric Dentistry, University Clinic of Dentistry, Medical University of Vienna, Vienna, Austria ${ }^{4}$ Department of Oral Basic \& Clinical Sciences, Faculty of Dentistry, Umm Al-Qura University, Makkah, Saudi Arabia ${ }^{5}$ Section of Orthodontics, Department of Neurosciences, University of Naples “Federico II," Naples, Italy

${ }^{6}$ Department of Prosthetic Dentistry, University Medical Center Hamburg - Eppendorf, Hamburg, Germany ${ }^{7}$ Department for Prosthodontics, Faculty of Dental Medicine, University Ss. Cyril and Methodius, Skopje, Macedonia ${ }^{8}$ Department of Periodontics, Care Dental College, Guntur, Andhra Pradesh, India

${ }^{9}$ Department of Periodontology and Community Dentistry, University of Ibadan and University College Hospital, Ibadan, Nigeria

${ }^{10}$ Department of Orofacial Pain and Jaw Function, Faculty of Odontology, Malmö University, Malmö, Sweden

${ }^{11}$ Department of Prosthodontics, School of Dental Medicine and Clinical Hospital Centre, University of Zagreb, Zagreb, Croatia ${ }^{12}$ Clinic for Dentistry of Vojvodina, Faculty of Medicine, University of Novi Sad, Novi Sad, Serbia

${ }^{13}$ Department of Orofacial Pain, Faculty of Medicine, University of Desarrollo, Santiago, Chile

${ }^{14}$ Department of Prosthodontics, School of Dentistry, Showa University, Tokyo, Japan

${ }^{15}$ Department of Reconstructive Dentistry and Gerodontology, University of Bern, Bern, Switzerland

${ }^{16}$ Division of Gerodontology and Removable Prosthodontics, University Clinics of Dental Medicine, University of Geneva, Geneva, Switzerland

${ }^{17}$ Department of Child Health and Orthodontics, Kwame Nkrumah University of Science and Technology, Kumasi, Ghana ${ }^{18}$ Department of Oral Medicine and Periodontology, Faculty of Dental Sciences, University of Peradeniya, Peradeniya, Sri Lanka

${ }^{19}$ Department of Prosthodontics, Faculty of Dentistry with Clinics, University of Sarajevo, Sarajevo, Bosnia and Herzegovina ${ }^{20}$ Dental School, University of Sydney, Sydney, Australia

${ }^{21}$ Department of Stomatology, Huashan Hospital, Fudan University, Shanghai, China

22Department of Dentistry and Oral Health, Aarhus University, Aarhus, Denmark

${ }^{23}$ Division of Pediatrics and Public Health, Division of Oral \& Craniofacial Health Sciences, Adams School of Dentistry, the University of North Carolina at Chapel Hill, North Carolina, USA

${ }^{24}$ Center for Headaches, Facial Pain and TMD, Punta Pacifica Medical Center, Panama City, Panama

${ }^{25}$ Oral Health Research Center, Health Research Institute, Babol University of Medical Sciences, Babol, IR Iran

${ }^{26}$ Instituto Patricia Valério, Belo Horizonte, Minas Gerais, Brazil

${ }^{27}$ Department of Anesthesia in Dentistry, Moscow State University of Medicine and Dentistry, Moscow, Russia ${ }^{28}$ Faculty of Dentistry, University of Khartoum, Khartoum, Sudan

${ }^{29}$ King's College London Dental Institute, Guy's Hospital, London, United Kingdom

${ }^{30}$ Department of Oral Medicine and Periodontology University of the Western Cape, Cape Town, South Africa

${ }^{31}$ Oral Surgery Department, Faculty of Dentistry of Rabat, Mohammed V University in Rabat, Rabat, Morocco

${ }^{32}$ Department of Research Affairs, Faculty of Dentistry, Chulalongkorn University, Bangkok, Thailand

${ }^{33}$ Department of Diagnostic and Biological Sciences, Faculty of Dentistry, Western University, Bangkok, Thailand

${ }^{34}$ Department of Prosthodontics, Faculty of Medicine, University of Ljubljana, Ljubljana, Slovenia

${ }^{35}$ Department of Prosthodontics, University Dental Clinics, University Medical Center Ljubljana, Ljubljana, Slovenia 


\section{ABSTRACT}

\section{Keywords:}

oral health, surveys, questionnaires, World Health Organization, Slovenia, oral health models, dentists, patients, dental specialties, dentistry

\section{IZVLEČEK}

\section{Ključne besede:} oralno zdravje, ankete, vprašalniki, Svetovna zdravstvena organizacija, Slovenija, modeli oralnega zdravja, zobozdravniki, pacienti, zobozdravstvene specializacije, zobozdravstvo
Objectives: To compare the frequency of patients' oral health problems and prevention needs among Slovenian and international dentists with the aim to validate the four oral health-related quality of life (OHRQOL) dimensions across six clinical dental fields in all World Health Organization (WHO) regions.

Methods: An anonymous electronic survey in the English language was designed using Qualtrics software. A probability sampling for Slovenia and a convenience sampling strategy for dentist recruitment was applied for 31 countries. Dentists engaged in six dental fields were asked to categorize their patients' oral health problems and prevention needs into the four OHRQoL dimensions (Oral Function, Orofacial Pain, Orofacial Appearance, and Psychosocial Impact). Proportions of patients' problems and prevention needs were calculated together with the significance of Slovenian and international dentists' differences based on dental fields and WHO regions.

Results: Dentists $(n=1,580)$ from 32 countries completed the survey. There were 223 Slovenian dentists (females: $68 \%$ ) with a mean age (SD) of $41(10.6)$ years and 1,358 international dentists (females: $51 \%$ ) with a mean age (SD) of 38 (10.4). Pain-related problems and prevention needs were the most prevalent among all six dental fields reported by dentists; Slovenian (37\%) and 31 countries (45\%). According to Cohen, differences between Slovenia, the broader European Region, and 31 countries were considered non-significant $(<0.1)$.

Conclusion: According to the dentists' responses, the frequency of patients' oral health problems and prevention needs are proportionate between Slovenia and 31 countries, regionally and globally. The four OHRQoL dimensions can be considered universal across all dental fields.

Namen: $V$ raziskavi smo želeli primerjati pogostost ustno-obraznih težav in potreb po preventivnem zdravju zobozdravstvenih pacientov med slovenskimi in mednarodnimi zobozdravniki s pomočjo spletne ankete, ki bi potrdila veljavnost štirih dimenzij oralnega zdravja $v$ šestih kliničnih zobozdravstvenih specialnostih iz vseh svetovnih regij, kot jih določa Svetovna zdravstvena organizacija.

Metode: $V$ programski opremi Qualtrics smo v angleškem jeziku izdelali anonimno spletno anketo z namenom kategorizirati ustno-obrazne težave in preventivne ukrepe zobozdravstvenih pacientov $v$ štiri dimenzije oralnega zdravja (funkcionalna, bolečinska, estetska in psihosocialna) na osnovi šestih stomatoloških specialnosti. Naključno vzorčenje smo uporabili za slovenske zobozdravnike, medtem ko smo za zobozdravnike iz 31 držav uporabili priložnostno vzorčenje. Za preverjanje pacientovih ustno-obraznih težav ter njihove potrebe po zdravljenju na osnovi zobozdravnikove ocene smo uporabili razmerja v odstotkih. Velikost učinka smo računali za preverjanje razlik med slovenskimi in tujimi zobozdravniki iz vseh regij po razdelitvi Svetovne zdravstvene organizacije in na osnovi šestih zobozdravstvenih specialnosti.

Rezultati: Tisoč petsto osemdeset zobozdravnikov iz 32 držav je izpolnilo spletno anketo. Od tega je bilo 223 slovenskih (68 \% žensk) s povprečno starostjo (SD) $41(10,6)$ let in 1.358 tujih zobozdravnikov $(51 \%$ žensk) s povprečno starostjo (SD) $38(10,4)$ let. Slovenski $(37 \%)$ in tuji $(45 \%)$ zobozdravniki so izbrali ustnoobrazno bolečino kot najpogostejšo težavo in preventivni ukrep pri zobozdravstvenih pacientih $v$ vseh šestih zobozdravstvenih specialnostih. Po Cohenu so bile razlike med slovenskimi in pacienti iz drugih držav z ustnoobraznimi težavami in pri preventivnih ukrepih zelo majhne $(<0,1)$.

Zaključek: Ustno-obrazne težave zobozdravstvenih pacientov in njihove potrebe po zdravljenju znotraj vseh šestih zobozdravstvenih specialnosti so $v$ Sloveniji in drugih 31 državah, regionalno in globalno, primerljive. Vse štiri dimenzije podpirajo zobozdravnikov celostni pogled na oralno zdravje in preventivne ukrepe zobozdravstvenih pacientov po svetu in zobozdravstvenih specialnostih. 


\section{INTRODUCTION}

At least 13 different oral health models exist $(1,2)$, providing dentists and researchers a theoretical framework with the most comprehensible explanation of the oral health-related quality of life (OHRQoL) (3) concept. An empirically derived oral health model defined by Oral Function, Orofacial Pain, Orofacial Appearance, and Psychosocial Impact dimensions was introduced in 2014 $(4,5)$. These four dimensions were found to be valid based on exploratory and confirmatory factor analysis (4-6) using dental patient-reported outcome measure (dPROM) data (7) via the 49-item Oral Health Impact Profile (OHIP-49) (8) obtained from more than 10,000 dental patients and general-population subjects from six countries. While the original authors assumed the four dimensions to be universal for oral health, this assumption has not been tested across dental fields. Various dental fields are recognized under dentistry, and they are all essential to provide the best treatment for a specific disease-oriented orofacial condition. Although dental fields are defined and named differently in various countries, they all share the same purpose, namely to restore and improve patients' functional, pain-related, aesthetic, and psychosocial disorders related to their entire orofacial system, which in turn improves their quality of life. Therefore, by practicing various dental fields, it is possible to assess the four OHRQoL dimensions in patient care, public health, research, and education.

Most dentists work with patients daily and are aware of why their patients seek oral health care, i.e. due to functional, pain-related, aesthetic, and psychosocial problems associated with their oral health concerns $(9,10)$. Patients also visit dentists to prevent possible problems (11). As a result, dentists try to eliminate or alleviate patients' orofacial pain, restore or improve their function, improve orofacial aesthetics, and help patients with their psychosocial concerns, e.g. increase their possible low selfesteem by applying aesthetic restorative dental treatments or by counseling about halitosis and tooth discoloration (12). In essence, the dentist's role is to diagnose oral diseases, promote oral health and disease prevention, develop treatment plans to maintain or restore patients' oral health, interpret $x$-rays and diagnostic tests, ensure the safe administration of anesthetics, monitor the growth and development of the teeth and jaws, perform surgical procedures, and improve patients' OHRQOL $(13,14)$.

So far, only a few studies have evaluated patients' problems based on dental professionals' perspectives. Authors have utilized electronic surveys to assess patient-specific factors related to oral health based on international health professionals' estimation grouped into six world regions defined by the World Health Organization (WHO) (15-17). A study by Dougall et al. (16) used the online Global Oral
Health Survey to explore functioning, participation, social environment, and other factors concerning oral health based on the International Classification of Functioning, Disability, and Health (ICF) (18). Similarly, Faulks et al. (15) applied the ICF version for children and young people, an online Delphi survey, to investigate children's oral health from health practitioners' viewpoint. Research has not yet been conducted on evaluating patients' oral health problems and prevention needs, based on dentists' surveyed opinion, coinciding with the four OHRQoL dimensions within dental fields across countries belonging to all six WHO regions.

Because Slovenia is a relatively small country in the European Region with good oral health and the possibility of prompt dental care, we wanted to review patients' functional, pain-related, aesthetic, and psychosocial problems and prevention needs obtained through the opinion of dentists engaged in six clinical dental fields and compare them with international patients' oral health problems and prevention needs.

Thus, this study's objective was to compare the frequency of patients' oral health problems and prevention needs as reported by Slovenian and international dentists with the aim to validate the four OHRQoL dimensions across six clinical dental fields in all WHO regions.

\section{MATERIALS AND METHODS}

\subsection{Electronic survey}

Three authors (MTJ, KRS, and SS) designed and implemented an electronic survey (19) in the English language using the Qualtrics (Qualtrics, Utah) software. In the introductory part of the survey, dentists were informed about the goals and time required to complete it and the anonymity of data collection. Dentists were asked to evaluate their dental patients' orofacial problems and whether they fit into the four dimensions (Table 1).

\subsection{Study subjects}

Three study authors (KRS, MTJ, and SS) contacted one reference dentist from each of the 32 countries within the six WHO regions. The reference dentist was entitled as "center dentist" and had a task of recruiting and providing access to at least ten dentists working in his or her country from six dental fields, i.e. restorative dentistry, including endodontics and prosthodontics, periodontology, oral and maxillofacial surgery, pediatric dentistry, orthodontics, and oral medicine and/or temporomandibular disorders (TMD). Inclusion criteria were one center dentist per country, dentists (general dentists and/or specialists) with a valid dental license, dentists who have seen patients in the past year, and dentists with the ability to read, understand, and respond to a survey in the English 
Table 1. International dentists' survey's main questions.

1. Why did patients typically visit you when they had problems with their teeth (including dentures), mouth, or jaws? Please only consider the patients' primary problem!

The patients visited me because of:

$\%$ of patients:

Impaired oral function (eating, chewing, talking, etc.)

Pain (dental, oral, facial, etc.)

Broader psychosocial impacts/distress because of their oral health situation

Other problems not mentioned above

1.1. You mentioned that some patients had “...other problems not mentioned above".

Please write down the most important problem that does not fit into any of the four listed categories.

2. To assess how your patients match your most recent patients, please check the dental records or think of your last 10 patients with oral health problems. Please only consider the patients' primary problem!

How many patients came because of:

No. of patients:

Impaired oral function (eating, chewing, talking, etc.)

0

Pain (dental, oral, facial, etc.)

Impaired dental, oral, or facial appearance

Broader psychosocial impacts/distress because of their oral health situation

Other problems not mentioned above

2.1. You mentioned that some of your last 10 patients had “...other problems not mentioned above".

Please write down the most important problem that does not fit into any of the four listed categories.

3. Have any patients visited you primarily for a preventive check-up regarding their teeth

(including dentures), mouth, or jaws?

Yes, they have.

No, they visited me only when they had primarily problems with

their teeth (including dentures, mouth, or jaws).

3.1. Why did patients typically visit you when they come for a preventive check-up regarding their teeth (including dentures), mouth, or jaws? Please only consider the patients' primary intent!

They visited me because they wanted to prevent:

$\%$ of patients:

Impaired oral function (eating, chewing, talking, etc.)

Pain (dental, oral, facial, etc.)

Impaired dental, oral, or facial appearance

Broader psychosocial impacts/distress because of their oral health situation

Other intentions not mentioned above

4. Please choose one global assessment to describe how well the four problem categories (Function, Pain, Appearance, Psychosocial Impact) fit your patients' current and future oral health concerns.

Poor fit Fair fit Good fit Very good fit Excellent fit

language. The exclusion criterion was dental students. The country's minimum requirement to be included in the survey analyses was ten completed surveys per country.

\subsection{Data collection}

The study was conducted between May 2017 and July 2018. A probability sample of Slovenian dentists using simple random sampling, i.e. every member of the targeted dentist population had an equal chance of being included in the sample due to the small Slovenian population size, and a convenience sample of international dentists from 31 countries were invited to complete the online survey through the Medical Chamber of Slovenia or via e-mail, respectively. The 31 countries were grouped according to their assumed geographical similarity to Slovenia to detect 
cultural influences on OHRQoL data. We categorized countries according to the WHO region classification (17) (Figure 1).

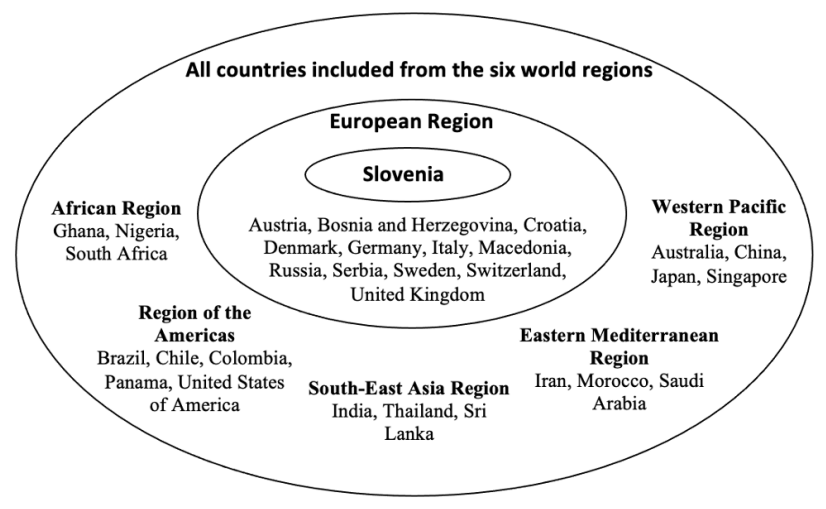

Figure 1. Distribution of participating countries as defined by the World Health Organization.

All active Slovenian dentists were invited in three waves, and dentists from 31 countries were contacted in eight waves. Center dentists were updated every week about the recruitment status and the number of collected responses per country. Non-response or center dentists' recruitment of fewer than ten dentists in a particular country was addressed by deleting that country from the analysis and recruiting another center dentist from the same or a different country.

\subsection{Data analysis}

If non-significant differences between different data collection methods were to be observed between Slovenia (probability sampling method) and other 31 countries (convenience sampling method), we hypothesized that Slovenia's findings would also be valid for other countries regarding the validity of the four oral health dimensions. The data collection method should not influence the data alignment into the four-dimensional oral health problems. We expect at least $75 \%$ coverage of functional, pain-related, aesthetic, and psychosocial problems and prevention needs in all clinical dental fields. Effect sizes between different data collection methods, i.e. different regions, should be small. If that were to be observed, the soundness of the four dimensions in clinical practice would be achieved. Missing data were handled by deleting dentists ( $n=329)$ who did not respond to three or all four of the survey's main questions. Slovenian and international dentists' responses were examined in percentages. Effect sizes and $95 \%$ confidence intervals were used to express differences between Slovenian and international dentists' responses, where $\mathrm{h}=0.2$ was considered "small", $\mathrm{h}=0.5$ "medium", and h=0.8 "large effect size", according to Cohen (20). All statistical analyses were performed based on percentages of dental patients' oral health problems and prevention needs categorizations based on dentists' responses from the six dental fields using the statistical software STATA (Stata Statistical Software: Release 14.2, rev.19; 2016, College Station, TX: StataCorp LP).

\section{RESULTS}

\subsection{Study subjects' characterization}

One thousand, five hundred eighty dentists provided information on more than 15,800 of their patients' oral health problems and prevention needs. Fifty-four percent of the respondents were females, with a mean age (SD) of 38 (10.5) years. Sixty-two percent of dentists were general dentists. Most dentists worked in restorative dentistry (70\%) and the fewest of them in orthodontics (15\%).

About $40 \%(n=646)$ of all international dentists, regardless of which sampling scheme entered the study, reported to work in a single dental field, namely 315 dentists worked in restorative dentistry, 83 in pediatric dentistry, 72 in orthodontics, 69 in periodontology, 59 in oral and maxillofacial surgery, and 47 in oral medicine and/or TMD (Figure 2). Out of 223 Slovenian dentists, only 83 reported working in only one dental field: 49 in restorative dentistry, 18 in pediatric dentistry, 10 in orthodontics, 4 in periodontology, 1 in oral and maxillofacial surgery, and 1 in oral medicine and/or TMD.

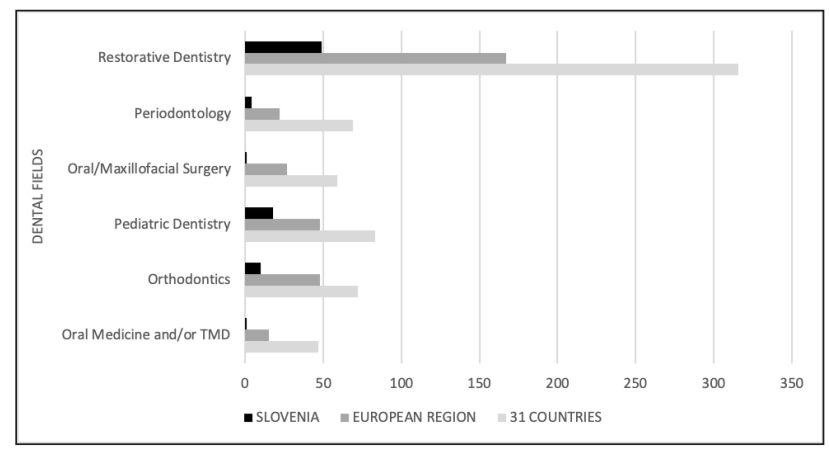

Legend: TMD - temporomandibular disorders

Figure 2. The numbers of dentists working in a single dental field in Slovenia, the European Region, and 31 countries. 
3.2 Distribution of international dentists' classification of their patients' oral health problems by dental fields

Slovenian dentists reported that dental patients' oral health problems related to pain were the most prevalent in pediatric dentistry with a mean of $47.8 \%$ and the least in orthodontics (25.4\%). Orofacial Appearance was the most prevalent problem in orthodontics $(40.7 \%)$. Dentists from 31 countries declared their dental patients most often sought help because of pain-related problems, reaching the highest mean value of $53.1 \%$ in pediatric dentistry and the lowest of $35.7 \%$ in orthodontics (Table 2).

Table 2. Proportions with $95 \%$ confidence intervals of four-dimensional OHRQoL problems within dental fields based on dentists' assessment from Slovenia, the European Region, and 31 countries.

\begin{tabular}{|c|c|c|c|c|c|c|}
\hline \multirow[t]{3}{*}{ Dental fields } & \multirow[t]{3}{*}{ Countries } & \multicolumn{5}{|c|}{ OHRQoL dimensions } \\
\hline & & $\begin{array}{l}\text { Oral } \\
\text { Function }\end{array}$ & $\begin{array}{l}\text { Orofacial } \\
\text { Pain }\end{array}$ & $\begin{array}{l}\text { Orofacial } \\
\text { Appearance }\end{array}$ & $\begin{array}{l}\text { Psychosocial } \\
\text { Impact }\end{array}$ & $\begin{array}{l}\text { Non-categorized } \\
\text { problems }\end{array}$ \\
\hline & & \multicolumn{5}{|c|}{ Proportion $(95 \% \mathrm{Cl})$} \\
\hline \multirow[t]{3}{*}{$\begin{array}{l}\text { Restorative } \\
\text { Dentistry }\end{array}$} & Slovenia & $\begin{array}{l}29.1 \\
(26.3,32.0)\end{array}$ & $\begin{array}{l}39.7 \\
(36.3,43.2)\end{array}$ & $\begin{array}{l}19.0 \\
(16.9,21.2)\end{array}$ & $\begin{array}{l}7.5 \\
(6.3,8.6)\end{array}$ & $\begin{array}{l}4.4 \\
(2.9,5.8)\end{array}$ \\
\hline & European Region & $\begin{array}{l}26.2 \\
(24.6,27.8)\end{array}$ & $\begin{array}{l}40.9 \\
(38.8,43)\end{array}$ & $\begin{array}{l}19.9 \\
(18.5,21.3)\end{array}$ & $\begin{array}{l}7.3 \\
(6.6,7.9)\end{array}$ & $\begin{array}{l}5.6 \\
(4.5,6.6)\end{array}$ \\
\hline & 31 countries & $\begin{array}{l}24.0 \\
(22.8,25.2)\end{array}$ & $\begin{array}{l}46.1 \\
(44.4,47.7)\end{array}$ & $\begin{array}{l}18.2 \\
(17.2,19.2)\end{array}$ & $\begin{array}{l}6.6 \\
(6.2,7.1)\end{array}$ & $\begin{array}{l}4.9 \\
(4.2,5.6)\end{array}$ \\
\hline \multirow[t]{3}{*}{ Periodontology } & Slovenia & $\begin{array}{l}26.9 \\
(23.8,30.0)\end{array}$ & $\begin{array}{l}38.4 \\
(34.2,42.5)\end{array}$ & $\begin{array}{l}20.0 \\
(17.6,22.4)\end{array}$ & $\begin{array}{l}8.5 \\
(6.9,10.0)\end{array}$ & $\begin{array}{l}6.1 \\
(3.8,8.3)\end{array}$ \\
\hline & European Region & $\begin{array}{l}22.5 \\
(20.6,24.3)\end{array}$ & $\begin{array}{l}45.0 \\
(42.2,47.7)\end{array}$ & $\begin{array}{l}17.0 \\
(15.5,18.5)\end{array}$ & $\begin{array}{l}8.1 \\
(6.9,9.2)\end{array}$ & $\begin{array}{l}7.3 \\
(5.7,8.8)\end{array}$ \\
\hline & 31 countries & $\begin{array}{l}21.7 \\
(20.4,23.0)\end{array}$ & $\begin{array}{l}49.4 \\
(47.4,51.4)\end{array}$ & $\begin{array}{l}15.9 \\
(14.9,17.0)\end{array}$ & $\begin{array}{l}7.1 \\
(6.4,7.8)\end{array}$ & $\begin{array}{l}5.6 \\
(4.7,6.6)\end{array}$ \\
\hline \multirow[t]{3}{*}{$\begin{array}{l}\text { Oral \& Maxillofacial } \\
\text { Surgery }\end{array}$} & Slovenia & $\begin{array}{l}28.8 \\
(24.6,33.0)\end{array}$ & $\begin{array}{l}36.5 \\
(32.3,41.8)\end{array}$ & $\begin{array}{l}22.2 \\
(18.0,26.4)\end{array}$ & $\begin{array}{l}7.5 \\
(6.0,8.9)\end{array}$ & $\begin{array}{l}4.7 \\
(2.7,6.8)\end{array}$ \\
\hline & European Region & $\begin{array}{l}23.7 \\
(21.4,26.0)\end{array}$ & $\begin{array}{l}46.0 \\
(42.5,49.6)\end{array}$ & $\begin{array}{l}16.8 \\
(14.8,18.8)\end{array}$ & $\begin{array}{l}6.8 \\
(5.8,7.9)\end{array}$ & $\begin{array}{l}6.4 \\
(4.3,8.4)\end{array}$ \\
\hline & 31 countries & $\begin{array}{l}21.1 \\
(19.6,22.7)\end{array}$ & $\begin{array}{l}51.7 \\
(49.4,54.1)\end{array}$ & $\begin{array}{l}15.3 \\
(14.1,16.6)\end{array}$ & $\begin{array}{l}6.4 \\
(5.7,7.1)\end{array}$ & $\begin{array}{l}5.2 \\
(4.0,6.3)\end{array}$ \\
\hline \multirow[t]{3}{*}{ Pediatric Dentistry } & Slovenia & $\begin{array}{l}21.8 \\
(18.1,25.5)\end{array}$ & $\begin{array}{l}47.8 \\
(42.7,52.9)\end{array}$ & $\begin{array}{l}16.0 \\
(13.3,18.8)\end{array}$ & $\begin{array}{l}6.6 \\
(4.9,8.3)\end{array}$ & $\begin{array}{l}7.5 \\
(4.0,11.1)\end{array}$ \\
\hline & European Region & $\begin{array}{l}19.1 \\
(17.3,20.9)\end{array}$ & $\begin{array}{l}49.5 \\
(46.7,52.4)\end{array}$ & $\begin{array}{l}16.0 \\
(14.2,17.8)\end{array}$ & $\begin{array}{l}8.0 \\
(6.8,9.1)\end{array}$ & $\begin{array}{l}7.2 \\
(5.3,9.0)\end{array}$ \\
\hline & 31 countries & $\begin{array}{l}17.9 \\
(16.6,19.2)\end{array}$ & $\begin{array}{l}53.1 \\
(51.0,55.2)\end{array}$ & $\begin{array}{l}15.6 \\
(14.2,16.9)\end{array}$ & $\begin{array}{l}6.9 \\
(6.2,7.7)\end{array}$ & $\begin{array}{l}6.2 \\
(5.0,7.4)\end{array}$ \\
\hline \multirow[t]{3}{*}{ Orthodontics } & Slovenia & $\begin{array}{l}17.0 \\
(10.3,23.8)\end{array}$ & $\begin{array}{l}25.4 \\
(13.7,37.1)\end{array}$ & $\begin{array}{l}40.7 \\
(26.6,54.8)\end{array}$ & $\begin{array}{l}6.0 \\
(3.1,9.0)\end{array}$ & $\begin{array}{l}10.6 \\
(2.7,18.4)\end{array}$ \\
\hline & European Region & $\begin{array}{l}17.4 \\
(15.0,19.8)\end{array}$ & $\begin{array}{l}32.2 \\
(27.6,36.8)\end{array}$ & $\begin{array}{l}32.5 \\
(27.8,37.2)\end{array}$ & $\begin{array}{l}9.7 \\
(7.5,11.8)\end{array}$ & $\begin{array}{l}8.0 \\
(4.7,11.4)\end{array}$ \\
\hline & 31 countries & $\begin{array}{l}16.8 \\
(15.0,18.7)\end{array}$ & $\begin{array}{l}35.7 \\
(31.9,39.5)\end{array}$ & $\begin{array}{l}32.7 \\
(28.9,36.4)\end{array}$ & $\begin{array}{l}8.2 \\
(6.8,9.7)\end{array}$ & $\begin{array}{l}6.3 \\
(4.2,8.4)\end{array}$ \\
\hline \multirow[t]{3}{*}{$\begin{array}{l}\text { Oral Medicine } \\
\text { and/or TMD }\end{array}$} & Slovenia & $\begin{array}{l}26.0 \\
(20.1,31.9)\end{array}$ & $\begin{array}{l}34.1 \\
(25.8,42.5)\end{array}$ & $\begin{array}{l}25.2 \\
(18.4,32.0)\end{array}$ & $\begin{array}{l}8.2 \\
(5.7,10.7)\end{array}$ & $\begin{array}{l}6.3 \\
(1.4,11.2)\end{array}$ \\
\hline & European Region & $\begin{array}{l}24.6 \\
(22.0,27.2)\end{array}$ & $\begin{array}{l}44.5 \\
(40.8,48.1)\end{array}$ & $\begin{array}{l}16.4 \\
(14.2,18.6)\end{array}$ & $\begin{array}{l}7.8 \\
(6.5,9.1)\end{array}$ & $\begin{array}{l}6.5 \\
(4.2,8.8)\end{array}$ \\
\hline & 31 countries & $\begin{array}{l}22.8 \\
(20.8,24.8)\end{array}$ & $\begin{array}{l}48.7 \\
(45.9,51.4)\end{array}$ & $\begin{array}{l}15.6 \\
(14.0,17.3)\end{array}$ & $\begin{array}{l}6.9 \\
(6.0,7.8)\end{array}$ & $\begin{array}{l}5.7 \\
(4.2,7.1)\end{array}$ \\
\hline
\end{tabular}

Legend: OHRQOL - oral health-related quality of life; TMD - temporomandibular disorders; $95 \% \mathrm{Cl}$ - confidence interval 
According to Cohen, the differences between Slovenian and international (European Region and 31 countries) patients' problems within the six dental fields were very small (Figure 3) based on the dentists' surveyed opinion. The largest difference was observed between Slovenia and 31 countries in the pain-related problem group -0.15 (95\% Cl: $-0.24,-0.08)$, followed by the European Region of -0.13 (95\% Cl: $-0.13,0.02)$.

\subsection{Distribution of international dentists' classification of their patients' prevention needs by dental fields}

The highest proportions were found within pain-related problems in all six dental fields and all country groupings (Table 3). In Slovenia, the highest proportion of painrelated problems was in pediatric dentistry (48.3\%). The highest proportion of pain-related problems in the European Region was within oral and maxillofacial surgery (38.5\%), and in the 31 countries was within periodontology
(38.2\%). The lowest proportions were observed in noncategorized problems followed by psychosocial problems, regardless of the dental field and country.

When Slovenian and international (European Region and 31 countries) patients' prevention needs, based on the dentists surveyed opinion, by the six dental fields were compared, differences were small, according to Cohen (Figure 4). The largest differences of 0.11 (95\% Cl: 0.03 , 0.21) were found for pain-related problems between Slovenia and 31 countries in all dental fields, followed by very small differences in Orofacial Appearance 0.09 (95\% Cl: 0.17, 0.01) and Psychosocial Impact 0.06 (95\% Cl: 0.15, 0.03 ) in all dental fields, and no differences in Oral Function 0.01 (95\% Cl: $0.08,0.07)$ and non-categorized problems 0.01 (95\% Cl: $0.12,0.15)$ in all dental fields. No differences were found between Slovenia and the European Region 0.00 (95\% Cl: $0.10,0.06)$ in the four dimensions and all dental fields.

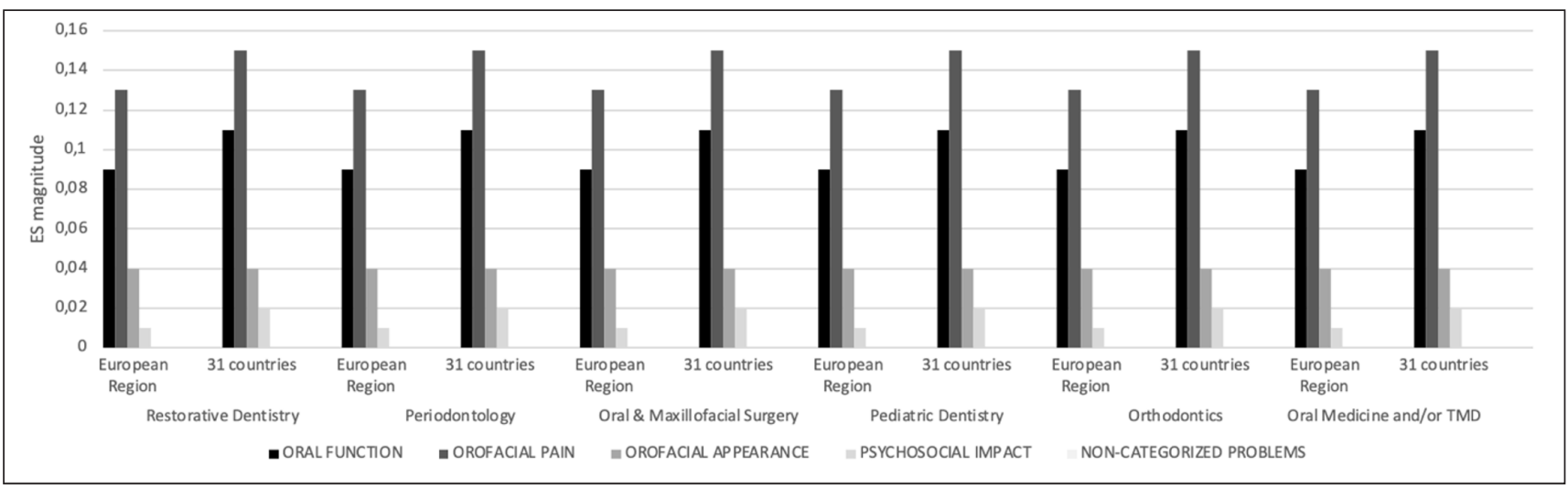

Legend: OHRQoL oral health-related quality of life; ES - effect size; TMD - temporomandibular disorders

Figure 3. The magnitude of four-dimensional OHRQoL problems based on dentists' assessments per dental field in Slovenia, the European Region, and 31 countries.

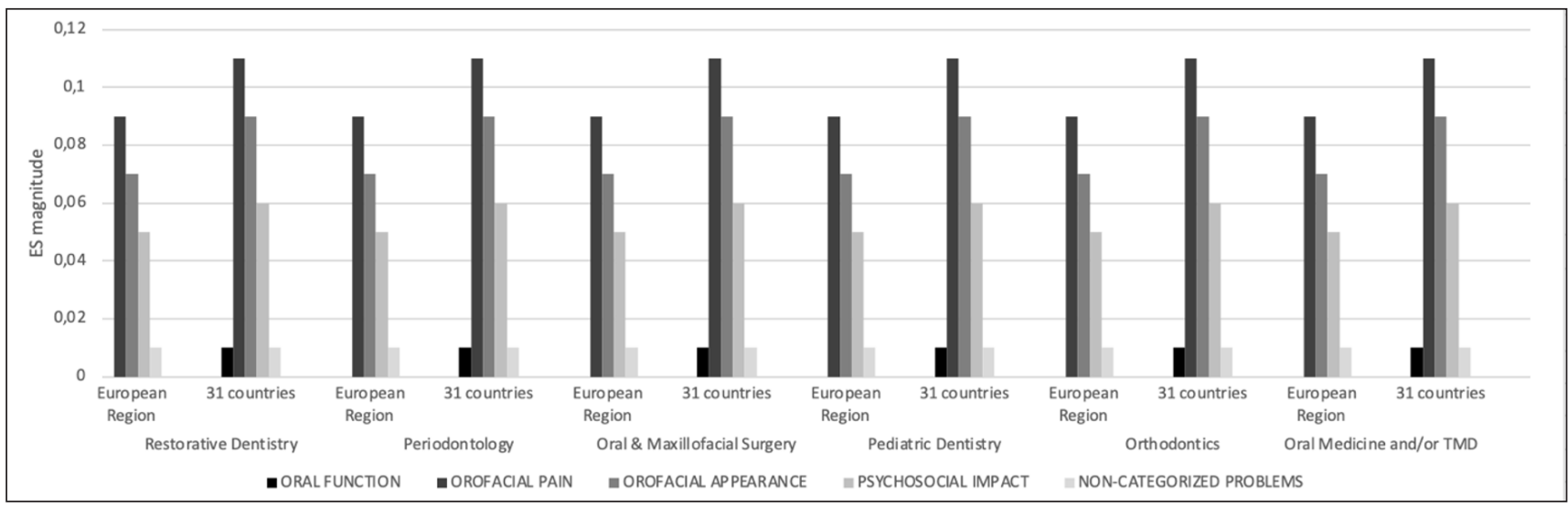

Legend: OHRQoL - oral health-related quality of life; ES - effect size; TMD - temporomandibular disorders

Figure 4. The magnitude of four-dimensional OHRQoL prevention needs based on dentists' assessments per dental field in Slovenia, the European Region, and 31 countries. 
Table 3. Proportions of four-dimensional OHRQoL prevention needs within dental fields based on dentists' assessment from Slovenia, the European Region, and 31 countries.

\begin{tabular}{|c|c|c|c|c|c|c|}
\hline \multirow[t]{3}{*}{ Dental fields } & \multirow[t]{3}{*}{ Countries } & \multicolumn{5}{|c|}{ OHRQoL dimensions } \\
\hline & & $\begin{array}{l}\text { Oral } \\
\text { Function }\end{array}$ & $\begin{array}{l}\text { Orofacial } \\
\text { Pain }\end{array}$ & $\begin{array}{l}\text { Orofacial } \\
\text { Appearance }\end{array}$ & $\begin{array}{l}\text { Psychosocial } \\
\text { Impact }\end{array}$ & $\begin{array}{l}\text { Non-categorized } \\
\text { problems }\end{array}$ \\
\hline & & \multicolumn{5}{|c|}{ Proportion $(95 \% \mathrm{Cl})$} \\
\hline \multirow[t]{3}{*}{$\begin{array}{l}\text { Restorative } \\
\text { Dentistry }\end{array}$} & Slovenia & $\begin{array}{l}24.1 \\
(20.8,27.3)\end{array}$ & $\begin{array}{l}44.7 \\
(40.4,49.0)\end{array}$ & $\begin{array}{l}16.6 \\
(14.0,19.2)\end{array}$ & $\begin{array}{l}6.3 \\
(4.3,8.3)\end{array}$ & $\begin{array}{l}8.1 \\
(4.4,11.9)\end{array}$ \\
\hline & European Region & $\begin{array}{l}26.7 \\
(24.4,28.9)\end{array}$ & $\begin{array}{l}38.2 \\
(35.5,40.8)\end{array}$ & $\begin{array}{l}21.4 \\
(19.5,23.3)\end{array}$ & $\begin{array}{l}7.1 \\
(5.9,8.2)\end{array}$ & $\begin{array}{l}6.4 \\
(4.4,8.5)\end{array}$ \\
\hline & 31 countries & $\begin{array}{l}25.4 \\
(23.7,27.2)\end{array}$ & $\begin{array}{l}37.4 \\
(35.3,39.5)\end{array}$ & $\begin{array}{l}22.1 \\
(20.5,23.7)\end{array}$ & $\begin{array}{l}8.3 \\
(7.2,9.4)\end{array}$ & $\begin{array}{l}6.5 \\
(5.0,8.1)\end{array}$ \\
\hline \multirow[t]{3}{*}{ Periodontology } & Slovenia & $\begin{array}{l}24.6 \\
(20.4,28.7)\end{array}$ & $\begin{array}{l}44.1 \\
(38.9,49.4)\end{array}$ & $\begin{array}{l}17.7 \\
(14.4,21.1)\end{array}$ & $\begin{array}{l}6.3 \\
(3.7,8.9)\end{array}$ & $\begin{array}{l}7.1 \\
(2.7,11.4)\end{array}$ \\
\hline & European Region & $\begin{array}{l}26.7 \\
(23.7,29.6)\end{array}$ & $\begin{array}{l}39.0 \\
(35.8,42.2)\end{array}$ & $\begin{array}{l}20.1 \\
(17.7,22.5)\end{array}$ & $\begin{array}{l}6.8 \\
(5.4,8.3)\end{array}$ & $\begin{array}{l}7.2 \\
(4.2,10.2)\end{array}$ \\
\hline & 31 countries & $\begin{array}{l}24.8 \\
(22.6,26.9)\end{array}$ & $\begin{array}{l}38.2 \\
(35.7,40.8)\end{array}$ & $\begin{array}{l}21.7 \\
(19.6,23.7)\end{array}$ & $\begin{array}{l}8.7 \\
(7.3,10.2)\end{array}$ & $\begin{array}{l}6.4 \\
(4.3,8.4)\end{array}$ \\
\hline \multirow[t]{3}{*}{$\begin{array}{l}\text { Oral \& Maxillofacial } \\
\text { Surgery }\end{array}$} & Slovenia & $\begin{array}{l}29.8 \\
(24.1,35.5)\end{array}$ & $\begin{array}{l}38.9 \\
(32.4,45.5)\end{array}$ & $\begin{array}{l}18.4 \\
(13.7,23.2)\end{array}$ & $\begin{array}{l}5.1 \\
(2.8,7.3)\end{array}$ & $\begin{array}{l}7.5 \\
(1.5,13.5)\end{array}$ \\
\hline & European Region & $\begin{array}{l}27.8 \\
(23.6,32.1)\end{array}$ & $\begin{array}{l}39.2 \\
(34.6,43.9)\end{array}$ & $\begin{array}{l}19.6 \\
(16.4,22.8)\end{array}$ & $\begin{array}{l}6.0 \\
(4.2,7.8)\end{array}$ & $\begin{array}{l}7.1 \\
(3.1,11.1)\end{array}$ \\
\hline & 31 countries & $\begin{array}{l}23.7 \\
(21.0,26.3)\end{array}$ & $\begin{array}{l}37.4 \\
(34.2,40.7)\end{array}$ & $\begin{array}{l}22.2 \\
(19.5,24.9)\end{array}$ & $\begin{array}{l}10.1 \\
(7.9,12.3)\end{array}$ & $\begin{array}{l}6.3 \\
(3.7,8.9)\end{array}$ \\
\hline \multirow[t]{3}{*}{ Pediatric Dentistry } & Slovenia & $\begin{array}{l}20.6 \\
(16.3,24.9)\end{array}$ & $\begin{array}{l}48.3 \\
(41.6,54.9)\end{array}$ & $\begin{array}{l}17.8 \\
(13.6,21.9)\end{array}$ & $\begin{array}{l}7.1 \\
(3.8,10.3)\end{array}$ & $\begin{array}{l}6.1 \\
(1.6,10.6)\end{array}$ \\
\hline & European Region & $\begin{array}{l}25.5 \\
(22.6,28.3)\end{array}$ & $\begin{array}{l}38.5 \\
(34.9,42.2)\end{array}$ & $\begin{array}{l}21.0 \\
(18.5,23.5)\end{array}$ & $\begin{array}{l}7.9 \\
(6.2,9.5)\end{array}$ & $\begin{array}{l}6.9 \\
(4.0,9.8)\end{array}$ \\
\hline & 31 countries & $\begin{array}{l}23.2 \\
(21.0,25.5)\end{array}$ & $\begin{array}{l}38.2 \\
(35.3,41.1)\end{array}$ & $\begin{array}{l}24.0 \\
(21.5,26.4)\end{array}$ & $\begin{array}{l}8.1 \\
(6.7,9.5)\end{array}$ & $\begin{array}{l}6.2 \\
(4.1,8.3)\end{array}$ \\
\hline \multirow[t]{3}{*}{ Orthodontics } & Slovenia & $\begin{array}{l}16.1 \\
(8.1,24.2)\end{array}$ & $\begin{array}{l}26.9 \\
(11.3,42.4)\end{array}$ & $\begin{array}{l}38.3 \\
(22.6,54.0)\end{array}$ & $\begin{array}{l}4.7 \\
(0.5,8.9)\end{array}$ & $\begin{array}{l}13.8 \\
(0.3,27.2)\end{array}$ \\
\hline & European Region & $\begin{array}{l}24.1 \\
(19.7,28.5)\end{array}$ & $\begin{array}{l}30.2 \\
(42.3,36.2)\end{array}$ & $\begin{array}{l}31.5 \\
(25.8,37.3)\end{array}$ & $\begin{array}{l}8.5 \\
(6.1,10.9)\end{array}$ & $\begin{array}{l}5.4 \\
(1.7,9.1)\end{array}$ \\
\hline & 31 countries & $\begin{array}{l}21.5 \\
(18.2,24.7)\end{array}$ & $\begin{array}{l}29.7 \\
(25.2,34.1)\end{array}$ & $\begin{array}{l}25.4 \\
(30.5,40.3)\end{array}$ & $\begin{array}{l}8.1 \\
(6.2,10.1)\end{array}$ & $\begin{array}{l}5.1 \\
(2.3,7.9)\end{array}$ \\
\hline \multirow[t]{3}{*}{$\begin{array}{l}\text { Oral Medicine } \\
\text { and/or TMD }\end{array}$} & Slovenia & $\begin{array}{l}31.4 \\
(22.0,40.7)\end{array}$ & $\begin{array}{l}37.0 \\
(27.7,46.2)\end{array}$ & $\begin{array}{l}17.2 \\
(9.3,25.0)\end{array}$ & $\begin{array}{l}3.4 \\
(-0.0,6.9)\end{array}$ & $\begin{array}{l}10.9 \\
(1.3,20.4)\end{array}$ \\
\hline & European Region & $\begin{array}{l}26.1 \\
(21.9,30.4)\end{array}$ & $\begin{array}{l}38.1 \\
(33.5,43.0)\end{array}$ & $\begin{array}{l}20.6 \\
(17.1,24.0)\end{array}$ & $\begin{array}{l}6.7 \\
(4.4,9.0)\end{array}$ & $\begin{array}{l}8.1 \\
(3.8,12.4)\end{array}$ \\
\hline & 31 countries & $\begin{array}{l}25.3 \\
(22.0,28.6)\end{array}$ & $\begin{array}{l}36.6 \\
(33.0,40.2)\end{array}$ & $\begin{array}{l}23.0 \\
(20.0,26.1)\end{array}$ & $\begin{array}{l}8.3 \\
(6.2,10.4)\end{array}$ & $\begin{array}{l}6.5 \\
(3.5,9.5)\end{array}$ \\
\hline
\end{tabular}

Legend: OHRQOL - oral health-related quality of life; TMD - temporomandibular disorders; $95 \% \mathrm{Cl}$ - confidence interval 


\section{DISCUSSION}

This study encompassed responses from 223 Slovenian and 1,357 international dentists who provided information on approximately more than 15,800 patients. All six dental fields showed comparable classification of patients' problems and prevention needs, based on dentists' surveyed opinion, regardless of the country and the WHO region. Patients' pain-related problems and prevention needs were the most common reasons for visiting dentists in all WHO regions, as reported by dentists. Regardless of cultural and sampling differences between Slovenian and international dentists, the distribution of dental patients' oral health problems and prevention needs, based on the dentists' surveyed opinion, into the four OHRQoL dimensions is comparable.

Our study shares some similarities in methodological approach with previous research $(15,16)$ as we followed the WHO's regional classification and used international dentists' evaluation. However, their study participants were not only dentists but also other health professionals. Both studies reported more than $80 \%$ of a holistic aspect of oral health within a group of international professionals when considering ICF items' importance and other factors related to their studies $(15,16)$. Similarly, our results showed that international dentists comprehensively classified more than $90 \%$ of patients' problems and prevention needs into the four dimensions regardless of dental field and the country of origin.

Similarly, for sleep medicine, a research group (21) conducted an online survey of international health professionals' evaluation of patient-specific problems related to sleep disorders applying the ICF. In comparison, our online survey consisted of four main questions with offered answers in percentages or numbers. Moreover, we considered cultural and sampling differences while evaluating international dentists' responses. Dentists' clinical assessment of patients' oral health concerns is essential because it provides accurate data and reliable results (22). Such results make it possible to categorize patients' oral health problems and prevention needs for each dental field into four dimensions. Providing evidence that the four OHRQoL dimensions are a robust framework applicable for patient care, teaching, and research across all dental fields would accelerate its acceptance, promotion, and use worldwide.

Other studies used experts' opinions to create dPROMs by grouping dental patients' oral health problems into seven domains: Functional Limitation, Physical disability, Psychological discomfort, Physical disability, Psychological disability, Social disability, and Handicap (23), providing validity for OHIP-49 dPROM. Using experts to assign items to attributes, this approach was also applied in a recent systematic review identifying generic dPROMs where authors relied on their clinical expertise for item assignment (7). Although similar methods were used, none of those studies were done using the WHO's country classification by world regions (17) and clinically testing the four oral health dimensions.

Thirty-two countries and at least three countries per WHO region were included. The three most numerous and seven largest countries also participated in this study. Using the electronic survey, we included many dentists from all around the world, obtaining a large sample size. Collecting de-identified data, we ensured confidentiality and unbiased results. This strategy helped increase the credibility of our research results and the response rate. Nevertheless, we were unable to determine dentists' response rates, as their answers were unidentified. If a particular dentist was approached by the center dentist, we did not know whether he or she participated in the study, i.e. center dentists may have invited 30 people to perform the survey, but only 10 of them completed it. If participation were related to the frequency of patients' problems and prevention needs, our results would be biased. However, we believe this situation is not probable since we did not find any cause, i.e. demographic characteristics, as factors for functional, pain-related, aesthetic, and psychosocial oral health concerns related to the frequency of international patients' problems and prevention needs.

This study has some limitations, such as different sampling methods between Slovenia and other participating countries. Slovenian data had a different data collection methodology because we could invite all active dentists, due to the small population size, without influencing the four-dimensional problems. We could have calculated proportions, ES, and $95 \% \mathrm{Cl}$ for dentists' assessments that work in only one dental field, providing a complementary perspective. Due to different sampling methodologies and the insufficient number of dentists working in just one dental field, we omit such computations. The findings would result in being unstable just because of chance since the number of dentists was too low to be analyzed. We would have been left with problems in interpreting results as accurate or just caused by chance. We could have presented separate results for each WHO region. However, because of zero to small differences between dentists' evaluation from Slovenian, European Region, and 31 countries across dental fields, the results reporting findings for each WHO region would have been repeated. Except for Slovenia, we used a convenience sampling of international dentists due to a lack of performing a probability sampling. Despite the different sampling strategies between Slovenia and 31 countries, results did not influence the categorization of the four-dimensional problems and prevention needs within dental fields. However, due to other countries' convenience sampling, 
any of these could have been over- or sub-represented. Our goal was to target individual dental specialties. However, some difficulties arose in listing them all since specific specialties differ between countries in terms of name and number of recognized specialties by dental organizations in the 32 participating countries. Thus, we decided to use dental fields that cover all or most specialties performed internationally. Even though we encompassed only six dental fields, which could have been an essential factor that challenges the four dimensions' usefulness, the six spheres contained all relevant dental specialties, regardless of the country and the WHO region that dentists came from. Therefore, each participating dentist could have selected one or more of the proposed dental fields of interest.

Dental fields are known to have their specific purposes. For instance, prosthodontics $(24,25)$ covers the dimension of Oral Function primarily with the goal to restore patients' capacity to chew; orthodontics (26) targets mainly Orofacial Appearance where its predominant outcomes are physical diseases; TMD (27) has Orofacial Pain as a primary target, as it consists primarily of temporary or long-lasting severe pain and discomfort in the orofacial region. While physical disease measurement is different, impact measurement utilizing the four-dimensional set is the same. Likewise, the four OHRQoL dimensions' sum is always $100 \%$, despite the different dimensional distribution. With this approach, a structure measuring a particular dental field's target by applying the four OHRQoL dimensions was presented.

\section{CONCLUSIONS}

Slovenian and international dentists from six major dental fields have classified more than $90 \%$ of their patients' oral health problems and prevention needs into the four OHRQoL dimensions. Thus, according to the dentists surveyed, the frequency of patients' oral health problems and prevention needs is comparable between Slovenia and 31 countries, regionally and globally. Dental patients' functional, pain-related, aesthetic, and psychosocial problems and prevention needs can be considered universal across all dental fields, providing a global basis for the application of evidence-based dentistry (28, 29) and core content of provider-doctors' and patients' communication (30), as well as paving the way towards value-based oral health care (31).

\section{ACKNOWLEDGMENTS}

The authors sincerely thank all international dentists who completed the online survey.

\section{CONFLICTS OF INTEREST}

The authors declare that no conflicts of interest exist.

\section{FUNDING}

The study was supported by the National Institute of Dental and Craniofacial Research of the National Institutes of Health, USA, under the Award Numbers R01DE022331 and R01DE028059.

\section{ETHICAL APPROVAL}

This study was approved by the National Ethics Committee (NMEC; 0120-219/2017-3; KME 63/05/17) of the Republic of Slovenia on 16 May 2017, and by the Institutional Review Board of the University of Minnesota, the USA on 25 July 2017 (IRB ID: STUDY00000864).

\section{REFERENCES}

1. Sekulic S, Theis-Mahon N, Rener-Sitar K. A systematic scoping review of oral health models. Qual Life Res. 2019;28:2651-68. doi: 10.1007/ s11136-019-02206-9.

2. Sekulic S, John MT, Davey C, Rener-Sitar K. Association between oral health-related and health-related quality of life. Zdr Varst. 2020;59:6574. doi: 10.2478/sjph-2020-0009.

3. Baiju R, Peter E, Varghese N, Sivaram R. Oral health and quality of life: current concepts. J Clin Diagnostic Res. 2017;1:ZE21-6. doi: 10.7860/ JCDR/2017/25866.10110.

4. John MT, Reissmann DR, Feuerstahler L, Waller N, Baba K, Larsson P, et al. Exploratory factor analysis of the oral health impact profile. J Oral Rehabil. 2014;41:635-43. doi: 10.1111/joor.12192.

5. John MT, Feuerstahler L, Waller N, Baba K, Larsson P, Čelebić A, et al. Confirmatory factor analysis of the oral health impact profile. J Oral Rehabil. 2014;41:644-52. doi: 10.1111/joor.12191.

6. John MT, Reissmann DR, Čelebić A, Baba K, Kende D, Larsson P, et al. Integration of oral health-related quality of life instruments. J Dent. 2016;53:38-43. doi: 10.1016/j.jdent.2016.06.006.

7. Mittal H, John MT, Sekulić S, Theis-Mahon N, Rener-Sitar K. Patientreported outcome measures for adult dental patients: a systematic review. J Evid Based Dent Pract. 2019;19:53-70. doi: 10.1016/j. jebdp.2018.10.005.

8. Slade GD, Spencer AJ. Development and evaluation of the oral health impact profile. Community Dent Health. 1994;11:3-11.

9. Kushner R. Why patients really visit the dentist. Dent Today. 2001;20:144-7.

10. Michalak E, Łoboda J, Chomyszyn-Gajewska M. Reasons for patients' visits in the dental offices of Cracow in the years 2005-2006 and 20133014. Przegl Epidemiol. 2015;69:787-94,913-8.

11. Rosen M. Dental treatment: utilization, motivation and prevention: a behavioural study of why people seek dental care. J Dent Assoc S Afr. 1990;45:319-21.

12. Davis LG, Ashworth PD, Spriggs LS. Psychological effects of aesthetic dental treatment. J Dent. 1998;26:547-54. doi: 10.1016/s03005712(97)00031-6.

13. Greene SM, Tuzzio L, Cherkin D. A framework for making patientcentered care front and center. Perm J. 2012;16:49-53.

14. John MT, Reissmann DR, Čelebić A, Baba K, Kende D, Larsson P, et al. Integration of oral health-related quality of life instruments. J Dent. 2016;53:38-43. doi: 10.1016/j.jdent.2016.06.006. 
15. Faulks D, Molina G, Eschevins C, Dougall A. child oral health from the professional perspective - a global ICF-CY survey. Int J Pediatr Dent. 2016;26:266-80. doi: 10.1111/ipd.12195.

16. Dougall A, Molina GF, Eschevins C, Faulks D. A global oral health survey of professional opinion using the international classification of functioning, disability and health. J Dent 2015;43:683-94. doi: 10.1016/j.jdent.2015.04.001.

17. World Health Organization. Definition of regional groupings. Accessed January 27, 2020 at: http://www.who.int/healthinfo/global_burden_ disease/definition_regions/en/.

18. World Health Organization. International classification of functioning, disability and health (ICF). Accessed January 27, 2020 at: http://www. who.int/ classifications/icf/en/.

19. John MT, Sekulic S, Bekes K, Al-Harthy MH, Michelotti A, Reissmann DR, et al. Why patients visit dentists - a study in all WHO regions. J Evid Dent Pract. 2020;20:101459. doi: 10.1016/j.jebdp.2020.101459.

20. Cohen J. Power analysis for the behavioral sciences. New York: New York University, 1988.

21. Gradinger F, Boldt C, Högl B, Cieza A. Part 2. Identification of problems in functioning of persons with sleep disorders from the health professional perspective using the international classification of functioning, disability and health (ICF) as a reference: a worldwide expert survey. Sleep Med. 2011;12:97-101. doi: 10.1016/j. sleep.2010.08.008.

22. Hummel R, Bruers J, van der Galiën O, van der Sanden W, van der Heijden G. Outcome measures for oral health based on clinical assessments and claims data: feasibility evaluation in practice. BMC Oral Health. 2017;17:1-8. doi: 10.1186/s12903-017-0410-5.

23. Locker D. Measuring oral health: a conceptual framework. Community Dent Health. 1988;5:3-18.

24. Mukawa K, Higuchi D, Furuyama C, Baba K. Predicting patient-reported outcomes of dental implant treatment. Int J Oral Maxillofac Implants. 2018;33: 863-70. doi: 10.11607/jomi.6133.

25. Čelebić A, Peršić S, Kovačić I, Buković D, Lešić N, Rener-Sitar K. Comparison of three prosthodontic treatment modalities for patients with periodontally compromised anterior mandibular teeth: a 2-year follow-up study. Acta Stomatol Croat. 2019;53:4-16. doi: 10.15644/ asc53/1/1.

26. Bengtsson M, Wall G, Larsson P, Becktor JP, Rasmusson L. Treatment outcomes and patient-reported quality of life after orthognathic surgery with computer-assisted 2- or 3-dimensional planning: a randomized double-blind active-controlled clinical trial. Am J Orthod Dentofacial Orthop. 2018;153:786-96. doi: 10.1016/j.ajodo.2017.12.008.

27. Dahlström L, Carlsson GE. Temporomandibular disorders and oral health-related quality of life: a systematic review. Acta Odontol Scand. 2010;68:80-5. doi: 10.3109/00016350903431118.

28. Reissmann DR. Dental patient-reported outcome measures are essential for evidence-based prosthetic dentistry. J Evid Based Dent Pract. 2019;19:1-6. doi: 10.1016/j.jebdp.2019.01.003.

29. Hua F. Increasing the value of orthodontic research through the use of dental patient-reported outcomes. J Evid Based Dent Pract. 2019;19:99-105. doi: 10.1016/j.jebdp.2019.04.005.

30. Palaiologou A, Kotsakis GA. Dentist-patient communication of treatment outcomes in periodontal practice: a need for dental patient-reported outcomes. J Evid Based Dent Pract. 2020;20:101443. doi: $10.1016 /$ j.jebdp.2020.101443.

31. Listl S. Value-based oral health care: moving forward with dental patient-reported outcomes. J Evid Based Dent Pract. 2019;19:255-9. doi: $10.1016 /$ j.jebdp.2019.101344. 